\title{
Tran-Duc-Thao and the language of real life $\mathrm{e}^{\mathrm{t}}$
}

\section{Jacopo D'Alonzo}

Paris 3 - Sorbonne Nouvelle, UMR 7597 Histoire des théories linguistiques, Sapienza - Università di Roma, Laboratorio di Storia delle Idee Linguistiche, via Zenodossio 21, 00176 Roma, Italy

\section{A R T I C L E I N F O}

\section{Article history:}

Available online 27 July 2018

\section{Keywords:}

Tran-Duc-Thao

Language of real life

German ideology

Saussurean linguistics

Phenomenology

\begin{abstract}
A B S T R A C T
From the 1950s, the Vietnamese philosopher Tran-Duc-Thao (1917-1993) became interested in language origins. To him, the way to investigate the roots of human language was to suggest a semiotics that would be free from the primacy of arbitrary signs. Thao called his own semiotic project the 'semiology of real life'. The main source of that label is a passage of Marx's and Engels' German Ideology dealing with 'the language of real life'. Thao's semiotic model may allow us to better understand some of the assumptions and implications of this little-known Marxian notion. Like Marx and Engels, Thao was deeply convinced of the social origins of linguistic skills and insisted that language arose during cooperative collective goal-oriented activities. Thus, Thao regarded the language of real life as coextensive with the material activity and the material intercourse of humans. He went on to describe the motivated structure, the denotative function, and the context-related nature of what he saw as the most fundamental signs in human languages. To him, such signs also illustrated the first step in the development of human-specific linguistic skills. At the same time, in this way, Thao called explicitly into question Saussure's semiotic model.
\end{abstract} (c) 2018 Elsevier Ltd. All rights reserved.

\section{Introduction}

The relationship between Marxism and the language sciences has been widely debated for the past one hundred years. Nonetheless, historians and philosophers of the language sciences have rarely drawn attention to a fascinating notion Marx introduced in the German Ideology (1845-1846), namely the notion of the language of real life (Sprache des wirklichen Lebens; henceforth LRL). The present paper is not intended to be a 'complete' working out of this notion, or to record each occurrence of that expression in Marxist literature. In addition, the problematic of LRL transcends the narrow limits of the history of Marxism. For instance, independently of Marx, the notion of langage de la vie réelle was also employed by Charles Bally (cf. Curea, 2015: 74) to describe forms of communication in everyday life. It would be interesting to examine these similarities. Nonetheless, we will limit ourselves to general questions about the notion in Marxist literature and consider a relevant case of application of the notion in the work of the Vietnamese philosopher Tran-Duc-Thao (1917-1993).

As a means of suggesting the value of the notion of LRL, we begin by citing Marx's own words:

The production of ideas, of conceptions, of consciousness, is at first directly interwoven with the material activity and the material intercourse of men, the language of real life. Conceiving, thinking, the mental intercourse of men, at this stage still appears as the direct efflux of their material behaviour. The same applies to mental production as expressed

\footnotetext{
is I wish to express my gratitude to the Special Issue editor for his assistance. I would also like to thank the anonymous referees for their comments and suggestions. The usual disclaimer applies: the views expressed here are those of the author.

E-mail address: jacopo.dalonzo@gmail.com.
} 
in the language of politics, laws, morality, religion, metaphysics, etc. of a people. Men are the producers of their conceptions, ideas, etc.-real, active men, as they are conditioned by a definite development of their productive forces and of the intercourse corresponding to these, up to its furthest forms. Consciousness can never be anything else than conscious existence, and the existence of men is their actual life-process. If in all ideology men and their circumstances appear upside-down as in a camera obscura, this phenomenon arises just as much from their historical life-process as the inversion of objects on the retina does from their physical life-process. [Die Produktion der Ideen, Vorstellungen, des Bewußtseins ist zunächst unmittelbar verflochten in die materielle Tätigkeit und den materiellen Verkehr der Menschen, Sprache des wirklichen Lebens. Das Vorstellen, Denken, der geistige Verkehr der Menschen erscheinen hier noch als direkter Ausfluß ihres materiellen Verhaltens. Von der geistigen Produktion, wie sie in der Sprache der Politik, der Gesetze, der Moral, der Religion, Metaphysik usw. eines Volkes sich darstellt, gilt dasselbe. Die Menschen sind die Produzenten ihrer Vorstellungen, Ideen pp., aber die wirklichen, wirkenden Menschen, wie sie bedingt sind durch eine bestimmte Entwicklung ihrer Produktivkräfte und des denselben entsprechenden Verkehrs bis zu seinen weitesten Formationen hinauf. Das Bewußtsein kann nie etwas Andres sein als das bewußte Sein, und das Sein der Menschen ist ihr wirklicher Lebensprozeß. Wenn in der ganzen Ideologie die Menschen und ihre Verhältnisse wie in einer Camera obscura auf den Kopf gestellt erscheinen, so geht dies Phänomen ebensosehr aus ihrem historischen Lebensprozeß hervor, wie die Umdrehung der Gegenstände auf der Netzhaut aus ihrem unmittelbar physischen.] (Marx and Engels, 1998: 42; cf. Marx and Engels, 1958: 26)

The previous quotation requires a brief remark. Unfortunately, it is not possible in a limited space to comment on Marx's and Engels' theory of consciousness set out in the German Ideology in great detail. We will simply focus on some aspects of their theory. According to Marx, consciousness is nothing but conscious experience (das bewußte Sein) of the actual lifeprocess, (wirkliches Lebensprozeß) (Marx and Engels, 1998: 42; cf. Marx and Engels, 1958: 36). One index of this is the fact that conscious contents arise from interactions with both the surrounding environment and intercourse with others (Bewußtsein des bornierten Zusammenhanges mit andern Personen und Dingen außer dem sich bewußt werdenden Individuum) (Marx and Engels, 1998: 49; cf. Marx and Engels, 1958: 31). Consequently, there are no a priori concepts. Interestingly, consciousness is said to be as old as language (Marx and Engels, 1998: 49; cf. Marx and Engels, 1958: 30). According to Lecercle (2006: 94), in this quotation from Marx, 'language plays a similar role to the imagination in Kant, which, as is well known, serves as an intermediary, by means of its schemata, between intuition and understanding: language serves as an intermediary between real life and the ideas that derive from it.' If one is exploring the role of language in the formation of consciousness, three points must be kept in mind. Given the material nature of language, the mind is from the outset afflicted with matter, 'which here makes its appearance in the form of agitated layers of air, sounds [...]' (Marx and Engels, 1998: 49; cf. Marx and Engels, 1958: 30). Marx and Engels suggested that language is part of social labour and enables the material intercourse of humans (cf. Marx and Engels, 1998: 49; Marx and Engels, 1958: 30). Assuming that consciousness is affected by the socio-practical origin of language, consciousness is, therefore, from the very beginning 'a social product [ein gesellschaftliches Produkt]' (Marx and Engels, 1998: 49-50; cf. Marx and Engels, 1958: 31).

This, then, is the general picture of Marx's and Engels' approach to consciousness in their German Ideology. For our purposes, we should take note that the LRL is seen as 'practical, real consciousness' (Marx and Engels, 1998: 49; cf. Marx and Engels, 1958: 31). That raises the question whether the LRL was a sort of metaphor employed by Marx to describe real interactions among humans against the background of social praxis. The French philosopher Henri Lefebvre seems to accept this understanding of the notion. Here's how he describes the notion of LRL:

Representations, ideas, have their origin in the 'commerce' of individuals among themselves, in exchanges, in the communication of consciousnesses, in the real activities which constitute praxis (social practice). To formulate them, theorists are needed. They are individuals who think according to a group or a social class. These idéologues clarify and sum up the vague meanings, which appear here and there in praxis. They derive general, coherent, systematized theories as far as possible: ideologies, including religions, philosophies, morals. They therefore start from the 'language of real life' to elaborate their representations and create 'the language of politics, laws, religion, morality, philosophy' [Les représentations, les idées, ont leur origine dans le 'commerce' des hommes entre eux, dans les échanges, dans la communication des consciences, dans les activités réelles qui constituent la praxis (pratique sociale). Pour les formuler, il faut des théoriciens. Ce sont des individus qui pensent en fonction d'un groupe ou d'une classe sociale. Ces idéologues dégagent et unissent entre elles les significations vagues, écloses çà et là dans la praxis. Ils en tirent des thèses générales, cohérentes, systématisées autant que possible: les idéologies, y compris les religions, les philosophies, les morales. Ils partent donc de la 'langue de la vie réelle' pour élaborer leurs représentations et créer 'la langue de la politique, des lois, de la religion, de la morale, de la philosophie'.] (Lefebvre, 1966: 93; trans. mine: JDA)

It seems that Lefebvre did not link the communication among consciousnesses (la communication des consciences) with the LRL. To him, the LRL is nothing but a metaphor which serves to oppose real life to ideologies. In this way, the LRL is nothing but social praxis which embodies meanings and modes of thinking essential to everyday life activity. The role of ideologies is to suggest general theories of that praxis. In a similar way, the Italian semiotician Ferruccio Rossi-Landi argued that 'Marx talked about a Sprache des wirklichen Lebens referring to the material behaviour of humans in a labour relationship [Marx infatti parlava di una Sprache des wirklichen Lebens riferendosi al comportamento materiale di uomini in rapporto di lavoro]' (RossiLandi, 2016: 70; trans. mine: JDA). And he added that 'a fundamental heuristic instrument is the principle that humans 
communicate not only with their verbal behaviour, but also with all their non-verbal behaviour [uno strumento euristico fondamentale è il principio che l'uomo comunica non solo con il suo comportamento verbale, ma anche con tutto il suo comportamento non-verbale]' (Rossi-Landi, 2016). According to Rossi-Landi, the LRL is a more general behaviour than spoken language. The LRL is a 'language of things [linguaggio delle cose]', the semiotic structure of the whole behaviour of humans in a labour relationship. About the LRL, the French linguist Jean-Jacques Lecercle wondered

whether the expression 'the language of real life' is a simple metaphor, since 'real life' is no more liable to possess its language than flowers. And I would like to think that Marx's formula goes further. At first sight, this text repeats the materialist thesis that ideas have a material origin, in 'real life' understood as a material activity - i.e. labour and production - and material relations - i.e. social relations: language is the product of social relations which it helps to fix and develop. But why characterise this real life as 'language' or attribute a 'language' to it? Because the materialist thesis is, in fact, two-fold: it affirms not only that ideas have a material origin, but also that they have a material existence. And the material existence of ideas precisely takes the form of language and of the institutions constructed around it. (Lecercle, 2006: 94)

It is a little-known fact that the Vietnamese philosopher Tran-Duc-Thao suggested a semiological project under the sign of the notion of LRL. To him, the LRL was not a metaphor. Rather it is the shape that communication takes during collective activities. Exploring Thao's attempt to work out a position in which the notion of LRL plays a relevant role will enable us to better understand that notion. In investigating the way Thao gave significant attention to the LRL we will lay out a fascinating chapter in the history of the interactions between Marxism and linguistics. Readers will be introduced to Thao's approach to the study of language behaviour and - most important of all - they will be stimulated to reconsider the value of Thao's proposal. Nonetheless, before we address these questions, we must gain a clearer sense of what was and what was not distinctive about Thao's theory of language. A brief overview of Thao's life and works is therefore provided ${ }^{1}$.

\section{Thao's life and works}

It is extremely difficult to establish when Thao took an initial interest in issues relating to human language. Our working hypothesis will be that Thao's interest in linguistic topics was the result of his personal reflection on Husserlian phenomenology. To Thao, the phenomenological approach to the study of consciousness had not been radical enough because Husserl failed to understand the natural origins of consciousness. According to Thao, the evolution of species and then the development of human society offer a solid basis to understand the actual nature of consciousness. The easiest way to understand the formation of consciousness is by beginning with the study of the symbolic skills we can observe among mammals. Slowly, Thao became more and more interested in both the evolution of language and the phylogeny of humankind. In this way, he was forced to elaborate a new approach to studying consciousness in which the formation of human language was regarded as the key to a better understanding of the very formation of consciousness itself.

After having received a French baccalaureate degree in 1935, Thao left Hanoi and went to Paris where he became a student of the prestigious École Normale Supérieure in 1939. In 1942, Thao defended a thesis devoted to the phenomenological method. In 1944, he spent some time at the Husserl-Archive in Louvain (Belgium) where he read transcriptions of some of Husserl's unpublished writings. Meanwhile, Thao took part in the political activities of the Trotskyist Groupe bolchévik-léniniste indochinois (GBL) and got involved in the congress gathering the representatives of the Indochinese workers of France (Congrès des Indochinois de France) which took place in Avignon (December 1944). After WW2, Thao published several articles devoted to phenomenology and emerged as one of the most important scholars in phenomenology in France (see the comment by Revel, 1997: 101-102; Barthes, 1951; Cavaillès in Israël, 2005: 57; Lyotard, 1991: 51; Althusser, 1995: 176; Derrida, 2004: 117; Ricœur, 2004: 168).

After a brief period in which Thao was close to the existentialist trend (see Thao, 1946a), he broke decisively from Sartre's existentialism (see for instance Thao, 1948, 1949). Thao sharply criticised the way Sartre dismissed Marxism as a philosophical approach to the study of consciousness. To Thao, Marxism was a solid philosophical perspective which could not be strictly reduced to political actions. Moreover, Thao disagreed with Sartre's dualistic distinction between the dimension of subjectivity and the natural world. According to Thao, in fact, one of the main tasks of philosophy is to shed light on the natural origins of human consciousness, along with the analysis of its social origins.

At the end of the 1940s, Thao's philosophical project involved a radical criticism of existentialism from a materialist and anti-dualistic point of view. In the meantime, Thao became even more sympathetic with Marxism and his political engagement became more radical (see Thao, 1946a, 1946b, 1947a, 1947b). In 1951, Thao's political engagement for the independence of Vietnam led to him taking the decision to return to Vietnam. Before he moved back to Vietnam, Thao summarised and published some results of his research into phenomenology (see Thao, 1951). To Thao, Husserl failed to understand that the lived experience phenomenology described is nothing but the abstract moment of the real embodied life. For Thao, phenomenology dealt with the idealised and abstract image of the life of the body and did not take into account the fact that the contents of consciousness depend upon a more fundamental relationship between the organism and the

\footnotetext{
${ }^{1}$ For Thao's biographical information see Feron 2014, Giao 1988, Hémery 2013, Israël 2005, Papin 2013, Melançon 2016, Revel 1997, Thảo, 1991: 1-11; 1993, Thao 2004, 2013.
} 
environment. To some extent, after adopting a materialist perspective, Thao tried to re-evaluate certain ideas involved in Husserl's theory of consciousness and integrated them into a description of animal cognition. In this context, Thao gave up Husserl's way of thinking and assumed dialectical materialism as the theoretical framework into which phenomenology could be successfully integrated.

At the end of the First Indochina War (1954), Thao had been appointed as Director of the Department of History at the University of Hanoi. During the same period, Thao published some articles devoted to the history of Vietnam and to Vietnamese literature (see Aubert-Nguyen, 2013). He taught History of Philosophy at the University of Hanoi and at the Institute of Pedagogy. A Vietnamese transcription of Thao's lectures was published in 1995, The History of Thought before Marx (cf. Papin, 2013: 69; Thao, 2013: 96-102; cf. also Papin, 2013: 64). In 1957, Thao published two articles to support a movement for democratic reform. As a consequence, the Vietnamese Communist Party - deeply hostile to every kind of revisionism decided to arrest, try and imprison Thao until 1961 (cf. Papin, 2013: 79). He had been explicitly forbidden to publish articles or books in Vietnamese, so Thao restarted getting involved in French intellectual life. He wrote some articles in French and sent them to some French reviews. In the 1960s, he was engaged in a vast research project on the origin of consciousness and language, as evidenced by a series of articles collected in his 1973 Recherches sur l'origine du langage et de la conscience (Investigations into the Origin of Language and Consciousness; henceforth RLC; for more details see Federici, 1970, Caveing, 1974, Haudricourt, 1974, Frédéric, 1974, D’Alonzo, 2016).

Before turning to discussion of Thao's theory of language, it is worth noting some central aspects of the RLC which will be analysed more deeply in the following paragraphs. According to Thao (1951), language played a role in the formation of consciousness from the more general symbolic skills shared by other mammals. Nonetheless, language was simply the mental reflex of social praxis. Thao's perspective changed in his RLC: language is no longer a reflex of social life but rather an essential element of social practices. Given that one of the main goals of Thao's theory is the description of the phylogeny of human consciousness, he dealt with the main stages of the evolution of language on the assumption that language arose during collective activities among our ancestors. Here we should emphasise that Thao's hypothesis largely depended upon Engels' theory of the part played by labour in the formation of language set out in his Dialektik der Natur (Dialectic of Nature; cf. Marx and Engels, 1962a 444-455). Thao also suggested that the pointing gesture is the original form of consciousness. To substantiate his own hypothesis, Thao described the interactions of particular elements: physiology and anatomy, communication skills, tool-making, cognition, social relations, and the surrounding physical environment. Before dealing with Thao's attempt to suggest a general semiotics that enabled him to describe the signs employed by our ancestors, it is worth noting the central point of the RLC to be further analysed below. What we should keep in mind is that Thao's theory started from three hypotheses: i) consciousness emerges in and through language considered in its materiality and in its practical and operational function; ii) language is not an object but a process of mediation between humans and reality, between individuals, and between the individual and the individual's own self; iii) language cannot be studied as an autonomous reality but must be observed and examined within social and practical life.

\section{Thao and Saussure's semiology}

Faced with the problem of language origins, Thao proposed the existence of certain signs in which the relation between the signifier and the signified is not wholly arbitrary. In this way, we can go so far as to say that Thao broadened and completed the most popular semiological model of the 1960s, at least in the French-speaking world. Needless to say, that semiological model was the language-oriented semiology whose main outlines had been described by Ferdinand de Saussure in his posthumous Cours de linguistique générale (Course in General Linguistics, 1916; henceforth CLG). To underline this fact, between 1974 and 1975, Thao published two articles entitled De la phénoménologie à la dialectique matérialiste de la conscience (From Phenomenology to the Materialist Dialectic of Consciousness; see Thao, 1974, 1975) which served as an introduction, partly biographical and partly theoretical, to the RLC. In the first article, Thao almost exclusively dealt with the theory of the sign proposed in the CLG.

We should briefly mention the fact that the reputation of the CLG is inseparable from its drafting and especially its circulation (Puech, 2013a; see also the vulgata which Lepschy, 1966 talks about), and the history of European structuralisms must be seen against such a background (Puech, 2013b). In Saussure's posthumous book, now familiar pairs of concepts - such as diachrony/synchrony, langue/parole or signified/signifier - had been introduced. From the 1950s, these notions became the keywords of so-called 'structuralism' (see Dosse, 1991, 1992). However, in the France of the 1960s and 1970s, there was opposition to the structuralist thesis and, in particular, to key hypotheses as set out in the CLG. The critique of structuralism by a number of Marxist thinkers (e.g., Sève, 1984; Lefebvre, 1971) was particularly significant historically in establishing a relatively homogeneous position of strategic, ideological and theoretical opposition to the dominant structuralist discourse. Similarly, though quite independently, Thao also believed that his own hypothesis about language origins together with the semiology which was its theoretical support were radically in disagreement with certain hypotheses set out by the CLG and taken up by structuralism.

The first principle to which Thao took exception was that of the arbitrariness of the sign. Thao refused to assimilate all signs to the class of arbitrary signs. In his words: 'I was surprised by the boldness with which the principle of the arbitrariness of the sign, taken from the study of spoken language, was extended to all signs in general for the establishment of semiology as a general science of signs' (Thao, 2009a: 301 [1974: 39]). Consequently, Thao introduced his own (dialectical) semiological model which 'would study the immense variety of modes of expression and that is oriented toward an ideal - opposed to the 
scientific ideal of conventional distinction founded on the principle of the arbitrariness of the sign' (Thao, 2009a: 303 [1974: 40]). In other words, he did not agree with Saussure's assumption that, in order to become a science, semiology should merely study the arbitrary features of signs. Though semiology would have also to study natural signs, Saussure affirmed, it must solely focus on their conventional aspects. Against that, Thao even doubted that languages could be regarded as systems of arbitrary signs at all. Among the signs Thao's semiology was to deal with we can mention 'mimicry, ritual, symbol, various figurative processes, the infinity of gestures and physiological games that precede, but always accompany and sometimes substitute for speech - all finding their greatest fulfilment in art.' He collected those signs under the label 'general system of intrinsic, or aesthetic signs [le système général des signes intrinsèques, ou esthétiques].' Those signs are aesthetic (from the Greek aisthesis, sensation) exactly because they are characterised by the 'intrinsic expressiveness of the signifier.' In contrast to arbitrary signs, intrinsic signs do not depend upon social convention, formal structures, or negative and differential relationships among them. Thao acknowledged that the system of the signes intrinsèques is the base of the system of arbitrary signs because the so-called arbitrary signs actually rest on a foundation of (non-arbitrary) intrinsic signs. In turn, arbitrary signs are more sophisticated from an intellectual point of view, enabling us to give a clear and unambiguous form to our thoughts. This is the core of Thao's theory:

Quite clearly, the first system [the system of intrinsic signs] founds the second [that of arbitrary signs], since it directly demonstrates in sensible intuition the content of meaning to which the second gives a conventionally formally more distinct expression, in order to develop it at the discursive level. [Bien évidemment, c'est le premier système qui fonde le second, puisqu'il présente directement dans l'intuition sensible le contenu de signification, auquel le second donne une expression conventionnelle, formellement plus distincte, pour le développer sur le plan discursif.] (Thao, 2009a: 303 [1974: 40]).

To illustrate, the system of intrinsic signs directly exhibits the meaning of a given expression to perception. For instance, the pointing gesture is enough to understand what the partner is referring to. In other words, the point does not require any system of arbitrary signs to be understood because it directly refers to the thing itself. In a similar way, an aggressive and threatening tone is enough to understand the intention of the interlocutor. At a subsequent stage, the system of arbitrary signs gives the message a conventional and discursive expression. In the case of the pointing gesture, other signs add ancillary information to pointing. To put it another way, the indicative gesture performs a denotative function while other motivated and arbitrary signs add supplementary connotative information about the properties of the thing itself.

It seems that Thao conceived of Saussurean arbitrariness in terms of a conventional relationship between signifier and signified rather than in terms of non-motivation. In the way Thao conceived of Saussurean arbitrariness, the relationship between signifier and signified would be the result of an explicit agreement among speakers. By contrast, Saussure established that there is no reason why a given signifier is associated with a given signified. Nonetheless, Thao would show to what extent arbitrariness needs a pre-existing communicational, cognitive and social layer. In this way, the system of intrinsic signs could be regarded as a support for arbitrary (or conventional) signs.

Thao stated that it would be quite wrong to equate the system of intrinsic signs with the system of arbitrary signs. Nevertheless, what Thao intended to do is not to dismiss Saussurean linguistics but to theorise a new field of research, i.e. the system of intrinsic signs. This system is the base for every system of arbitrary signs, i.e., the field of study of Saussurean linguistics. It is not a question of replacing Saussurean semiology with another semiology, but of identifying a new semiology alongside that of Saussure. This new semiology focuses on intrinsic signs and their relationship with the real life of individuals, that is, in reference to their bodies, to the external world, and to the social environment.

In re-evaluating the role of non-wholly arbitrary signs, Thao was also led to oppose the Saussurean notion of value. If a sign refers to another sign in order to be understood and only exists by virtue of its relation to other signs, then, Thao added, 'the whole meaning of signs merely consists in their referring to one another, without ever referring directly to things' (1984: 33 [1973: 61]). Thus, the speaker is epistemically separated from physical reality. In Thao's words: 'we are practically enclosed in a world of signs, so that we no longer see what speaking of things could mean' (Thao, 1984: 33 [1973: 61], also criticising Jakobson, 1963: 41). In support of his position, Thao suggested that the Saussurean notion of value could be useful to describe the emergence of technical languages which are largely based on the inter-definition of terms. Nonetheless, technical languages need a pre-existing system of non-wholly conventional signs. There would, therefore, be a hierarchy in the production of signs ranging from the semio-linguistic relationship with reality in practical and social life to disciplinary metalanguages.

Thao was one of the few scholars who attributed a particular significance to the eminently economic source of the Saussurean notion of value (this matter is too broad to be covered in this paper; for some details see Sofia, 2013) and he was fascinated generally by the comparison between linguistics and economics. This comparison was further developed by other Marxist scholars who also disagreed with the self-enclosed conception of value in Saussure and tried to deepen the economic homology between signifier/signified and use value/exchange value (for instance, see Lefebvre, 1966; Goux, 1968; Schaff, 1968: 207; Baudrillard, 1972; Latouche, 1973; Rossi-Landi, 2016: 180-181; see also Bourdieu, 1977; Rossi-Landi, 2003, 1977). For Thao's part, he did not reject the validity of the concept of value in itself. He admitted that the differential relation among signs is essential for expressing nuances of meaning, for articulating precisely the many different meanings of the same word, for defining more accurately certain concepts and making them clear and distinct. What Thao criticised was the reduction of signification to value, since, according to him, signification also concerns i) the intrinsic value of signs which are not totally arbitrary; ii) the differential value of arbitrary signs, i.e. the Saussurean notion of value; iii) the relationship between signs and the transcendent entity (material reality, pre-linguistic experience, etc.) to which they refer. From that point 
of view, his treatment of Saussure's value was a criticism in the Kantian sense, concerned with the delimitation of the limits and legitimacy of the notion.

Interestingly, Thao (1974: 42) brought out similarities between Saussure's notion of value and Marx's criticism set out in Capital (1873) of the vulgar political economy of the 19th century (cf. Marx and Engels, 1962c: 49-160). While a detailed exposition of Thao's argument exceeds the scope of the present study, we limit ourselves here to the observation that, according to Thao, no explanation of the value of a sign could be possible without pointing to the real dimension of communication and production of signs. The abstract system of signs needs to be traced back to real acts of communication taking place in the social dimension. In other words, we have to take into account the social milieu surrounding the individual communicator. For Thao it is also necessary to distinguish between the value which a sign has in the system - its 'exchange value' in relation to other signs - and the value which a sign has in itself - value in the strict sense of intrinsic signification. To Thao, intrinsic signification is a property of some fundamental non-wholly arbitrary signs: they are the original datum, the prerequisite for every comparison or exchange between signs.

An argument against the notion of value similar to the one developed by Thao was used by another Marxist semiotician, Ferruccio Rossi-Landi. Rossi-Landi (2016: 234-235) argued that the signification of a word genealogically precedes the opposition of that word to other signs. Thus, an understanding of signification is assumed to be prior to theoretical analysis of the 'exchange value' of the sign. Nonetheless, Rossi-Landi's analysis ignored the actual signification of words because his aim was in fact to grasp sign values (and their phenomenal appearance as 'exchange value') (cf. Rossi-Landi, 2016: 238). As D’Urso (2014: 57; trans. mine: JDA) wrote, Rossi-Landi 'has limited his reflections to the phenomenal moment of the mercantile comparison of values, omitting what Capital has taught: exchange in the broad sense is also production and, therefore, production needs to be analysed and demystified [ha limitato la propria riflessione al momento fenomenico del confronto mercantile dei valori, tralasciando quanto gli aveva insegnato il Capitale, ossia che lo scambio in senso lato è anche produzione e che perciò è quest'ultima che bisogna analizzare e demistificare]' (the same remarks could be addressed to Schaff, $1968: 207$ or Bourdieu, 1977: 24). From this point of view, a great advantage of Thao's theory is that he did not reduce the value of signs to the differential relationships among them and, at the same time, he carried out research to explore the field of social production of intrinsic signs and fundamental significations. This is the field of the LRL.

As this discussion implies, there is a fundamental epistemological concern in Thao's theory. In philosophical terms, Saussurean 'structuralist' semiology would be an example of 'subjective reflection'. In such a case, the relationship of the individual to physical reality would be completely discounted. However, according to Lenin's Materialism and Empirio-Criticism (1908; see Lenin, 1972), the world exists prior to consciousness and independently of consciousness. Consequently, once we dismiss the relationship between language and mind-independent things, we lose a fundamental factor in the development of consciousness. However, through the pointing gesture, humans refer to an already existing world and it is only through the pointing gesture that consciousness of a mind-independent world (what Thao calls 'this here') can arise. Thao's semiology of real life therefore differs radically from Saussurean structuralist linguistics in that it does not rest upon synchronic relations among signs.

Against this background of assumptions, Thao's main aim was the description of the origins of phenomenological consciousness. According to him, subjective lived experience has two distinguishing characteristics: i) it is conscious; ii) it is intentional. Like Descartes, he argued that subjective lived experience must be regarded as an individual's inner experience and can only be described from the first-person perspective. As in Brentano, subjective lived experience was taken to refer to a given content (mental states and processes, things, properties and states of affairs, concepts, etc.). Given the primacy of the pointing gesture, Thao (2009b: 313 [1975: 25]) stated that

this gesture is thus the material constitutive movement of the actual real intentionality of consciousness [l'intentionalité effectivement réelle de la conscience] taken in its most fundamental form, that form by which consciousness is consciousness of the object in its objective reality [conscience de l'objet dans sa réalité objective], as existing beyond the subject and independently of it.

The pointing gesture was taken to involve the most fundamental relationship between humans and the physical environment.

Thao's hypothetical system of 'intrinsic signs' was also the theoretical basis for an approach to glottogenesis. Specifically, Thao (1974a, 1974b) believed that non-wholly arbitrary signs reveal what probably was the first example of human-specific communication. These signs should therefore be regarded as the fundamental elements of fully formed languages. Thus, he anchored language in a special kind of motivated sign, namely the pointing gesture. The peculiar nature of the human social environment changed the function that pointing has in other primates. The relation between the knowing subject and the thing indicated cannot be reduced to the animal-like relation between two terms: the subject and the object or the subject and other subjects. Among humans, the relationship with the real external world is embedded in social relations. Pointing, in other words, indicates the thing as the external target of common attention. As such, the thing becomes the object of several different perspectives at once, that is, the shared ground of human discourses (cf. Bimbenet, 2011: 308-310; cf. also recent studies concerning the development of language in the child: Schaffer, 1984: 79; Camaioni, 1993: 84; Tomasello, 1995: 106; Eilan et al., 2005: 5; Morgenstern et al., 2008). Pointing manifests both objective and intersubjective worlds in so far as the thing becomes the target of joint action and the simultaneous substrate of several different perspectives (cf. Bimbenet, 2011: 96). 


\section{The LRL and the origins of consciousness}

The present study compels us to highlight Thao's attempt to clarify the main properties of the système général des signes intrinsèques, leaving other questions open (see D'Alonzo, 2017a for more details). The first point we need to note for now is that he called his own semiological project sémiotique de la vie réelle. In his words: 'I believed I was able to place this material semiotics [sémiotique matérielle] under the concept, created by Marx, of a language of real life [langage de la vie réelle]' (Thao, 2009b: 317 [1975: 27]). Here we need to say a few words about two different translations of Marx's and Engels' passage devoted to the LRL. In this way, we will appreciate Thao's own understanding of that notion.

Interestingly, Thao's translation differed from the French translation of Éditions sociales, i.e. the up-to-date available French translation of that epoch (see Marx and Engels, 1968: 59). He translated:

La production des idées, des représentations, de la conscience, est tout d'abord immédiatement entrelacée dans l'activité matérielle et les relations matérielles des hommes, dans le langage de la vie réelle. La représentation, la pensée, les relations spirituelles des hommes apparaissent encore ici comme l'émanation directe de leur comportement matériel. [italics ours] (Thao, 1975: 27) [An available English translation reads: "The production of ideas, of conceptions, of consciousness, is at first directly interwoven with the material activity and the material intercourse of men, the language of real life. Conceiving, thinking, the mental intercourse of men, at this stage still appears as the direct efflux of their material behaviour." (Marx and Engels, 1998: 42)]

The translation of Éditions sociales was:

La production des idées, des représentations et de la conscience, est d'abord directement et intimement mêlée à l'activité matérielle et au commerce matériel des hommes, elle est le langage de la vie réelle. La représentation, la pensée, les relations spirituelles des hommes apparaissent encore ici comme l'émanation directe de leur comportement matériel. [italics ours] (Marx and Engels, 1968: 59)

Thao regarded the LRL as coextensive with the material activity and the material intercourse of humans. By contrast, the French translation identified the LRL with the production of ideas, of conceptions, of consciousness. To Thao, the LRL does not immediately coincide with the production of ideas, of conceptions, of consciousness but it is rather what production of ideas, of conceptions, of consciousness necessarily presupposes. Concerning the formation of human speech, Thao (1973, 1974, 1975) asserted that language arose along with collective labour among our pre-human ancestors. And he was interested in defining the nature of the first signs employed by our human ancestors to coordinate their collective activities.

The main element in Thao's approach to the problem of the LRL is the study of linguistic interaction in everyday life. This approach interfaces in multiple ways with sociology and sociolinguistics. Given that the LRL must be regarded as a substantial part of social life, Thao disagreed with every kind of cognitive analysis of language behaviour. He preferred to point out the socio-historical conditions of language behaviour, insisting that language cannot be divorced from the concrete forms of social intercourse. Of course, the relationship between language and social structures was widely debated in France in the mid-20th century (see for instance the works of Cohen, Mounin, Marcellesi, Gardin, Dubois, Calvet, Encrevé) but the distinctiveness of Thao's approach lay in his desire to explain the very origins of human consciousness. From a philosophical point of view, Thao interpreted the LRL as the very mode of existence of thinking, the means by which we can conceptualise our existence in the very experiencing of it. What Thao described under the label of LRL is a sort of collective intelligence, a shared group intelligence emerging from cooperative activities.

In a letter to the Italian semiotician Rossi-Landi, Thao described the main difference between his own approach to consciousness set out in 1951 and that suggested in his RLC: 'I failed to understand the indications Marx gave about language as a mediation between social practice and consciousness [il me manquait d'avoir compris les indications de Marx sur le langage, comme médiation entre la pratique sociale et la conscience]' (Hanoi, 27 January 1972; courtesy of the Department of Philosophy, University of Padua; for more details see D'Alonzo, 2017b). In line with his belated realization, Thao now wanted to describe how conscious contents are nothing but the internalisation of social practice. Furthermore, he had to demonstrate the material origins of consciousness without reducing higher mental activities to brain mechanisms. To solve this conundrum, he suggested that consciousness is the result of the internalisation of the LRL. On that basis, Thao argued that 'language is thus not simply the expression of thought or of consciousness' (1984: 16 [1973: 34]), rather language 'is consciousness itself in its "immediate reality".

Nevertheless, it must be noted that Thao did not regard the LRL as something that is 'as old as consciousness' in the same way Marx and Engels had done. Thus, Thao (1984: 17 [1973: 35]) argued for 'the existence of a language belonging to reality itself, prior to consciousness, from which consciousness draws its meaning.' Thao therefore insisted that language arises outside of consciousness. In this way, he transcended the age-old conundrum which marks the history of the debate on language origins: language presupposes consciousness as its source while consciousness needs language to develop 'consciousness presupposes language and language, consciousness' as Thao put it (1984: 19 [1973: 39]). Accordingly, Thao suggested that the meanings of linguistic signs do not depend upon a pre-existing consciousness that voluntarily gives them such meanings. Rather, the LRL is the very condition for having conscious contents and consciousness is nothing but the internalisation of meanings which are already at work in the LRL.

Thao's understanding of consciousness in this way was also influenced by Engels' theory of matter. According to Engels, motion in the most general sense must be conceived as the mode of existence, the inherent attribute, of matter (cf. Engels, 1987: 
362; Marx and Engels, 1962a: 354]). Matter is the sole ontological substrate of all that exists and takes the shape of different forms of motion. To Engels, the motion of matter could take the shape of basic mechanical motion, the motion of celestial bodies, chemical decomposition and combination, the motion of molecules, heat and light, electricity and magnetism, life, consciousness, thinking, etc. (cf. Marx and Engels, 1962a: 325, 575-576). Thao regarded the LRL as social matter, matière sociale. The LRL is material because it is composed of the concrete production of signs. It is social because it is involved in collective activities. To Thao, then, consciousness is nothing but the internalisation and idealisation of the 'social matter' of the LRL. At the same time, of course, consciousness is the result of the motion of the matter that composed the brain: "knowledge is the brain itself in its motion of thinking [dans son mouvement de connaissance]' (Thao, 1984: 29 [1973: 55]). But this peculiar motion of the brain requires the support of signs: 'consciousness must, therefore, be more exactly defined as the idealized form of motion of inner language [la conscience doit donc se définir plus précisément comme la forme idéalisée du mouvement du langage intérieur]' (Thao, 1984: 29 [1973: 56]). Let us now examine Thao's notion of 'inner language' more closely.

We have noted Thao's view that consciousness depends on the forms, conditions, and types of the LRL. Consciousness in itself, however, is considered to be nothing but inner speech, that is, the inner reproduction of language interactions. For this reason, Thao stated that 'the ideality of consciousness [l'idéalité de la conscience] is not some kind of ideality 'in itself, but is constituted in the actual motion of idealization [dans le mouvement effectif d'idéalisation] which is immediately implied in inner language' (Thao, 1984: 25 [1973: 49]). Let us try to unpack this idea. Firstly, consciousness arises from the internalisation of language behaviour, along with brain activity and body movements. Secondly, conscious contents take the shape language gives them. Here it is important to bear in mind Thao's view that 'language first of all objectively consists of material behaviour [comportement matériel] as the language of real life, a direct expression of material activity and of the material relations among workers' (Thao, 1984: 25). Thao argued that we speak on the basis of background knowledge, that is, more or less diffuse, mostly unproblematic, background convictions, traditions and common sense. From this point of view, the LRL is not an instrument at the speaker's disposal; there is no transparency of language, or of meaning at this level. The subject, rather, becomes a speaker by appropriating a language that is always and already collective. Thirdly, in so far as the LRL is a creation within a social milieu and takes the shape of an interchange, what the subject internalises is not just the bodily form of language behaviour and the relevant social meanings communicated through this interchange, but also the form of the dialogue itself. For Thao, the LRL 'raises itself to consciousness in inner language where the subject addresses himself starting with the image of the others in which he recognizes himself in the identity of his own lived experience [s'élève à la conscience dans le langage intérieur, où le sujet s'adresse à lui-même à partir de l'image des autres où il se reconnaît soi-même dans l'identité de son propre vécu]' (Thao, 1984: 29 [1973: 53]). As a consequence, the LRL provides both the form and the contents of conscious experience.

Nonetheless, and interestingly, through inner language consciousness 'stands out from the material movement which produces it [se détache du mouvement matériel que l'engendre]' (Thao, 1984: 27 [1973: 53]). This material movement simultaneously involves the bodily dispositions of a particular organism and the ensemble of social relations. Consciousness cannot therefore be separated from that material movement from which it 'stands out' (Thao, 1984). Indeed, consciousness exists in so far as it employs linguistic signs - which arose from concrete material social relations - and constantly requires the support of designed and performed body movements. For instance, Thao observed that the pointing gesture can take the shape of gaze motion in language interaction. In this way, the human gaze indicates the object to one's own self as well to others (Thao, 1984: 15). Thao emphasised that 'the material component [la composante matérielle] always remains present, in one way or another, in the ideal form' (Thao, 1984: 15 [1973: 32]). Consequently, inner language arose from the performance of such movements that the subject addresses to herself. For instance, gestural communication can also take the shape of exclamations or involuntary movements of throat and tongue (Thao, 1984: 16). In these cases, the subject is conscious of what has been meant (and thought) thanks to kinaesthesia and inner self-perceptions of bodily movements (Thao, 1984: 16).

But inner language is not only the internalisation of the LRL in its material nature, it is also the result of the internalisation of LRL in its social nature. According to Thao, 'social matter, in its linguistic layer, is defined as the ensemble of signifying acts, gestures and utterances, in the structure of reciprocity [la matière sociale dans sa couche linguistique, se définit comme l'ensemble des actes signifiants, gestes et voix, dans la structure de la réciprocité]' (Thao, 1984: 29 [1973: 51]). The structure of reciprocity is nothing other than language interactions. According to Thao (1973: 20), the image of the others leaves a trace in the brain of individuals: 'the enduring image of the social environment [l'image rémanente du milieu social]'. It follows that, in the flow of inner language, we take other people's perspectives, we explain our actions or describe ourselves from the point of view of others. To support this hypothesis, Thao invoked Marx's Capital (Marx and Engels, 1962c: 67, footnote 18). The German original version reads:

Da er weder mit einem Spiegel auf die Welt kommt noch als Fichtescher Philosoph: Ich bin ich, bespiegelt sich der Mensch zuerst in einem andren Menschen. Erst durch die Beziehung auf den Menschen Paul als seinesgleichen bezieht sich der Mensch Peter auf sich selbst als Mensch. Damit gilt ihm aber auch der Paul mit Haut und Haaren, in seiner paulinischen Leiblichkeit, als Erscheinungsform des Genus Mensch (Marx and Engels, 1962c: 67, footnote 18; italics mine: JDA). [The English translation reads: "In a sort of way, it is with man as with commodities. Since he comes into the world neither with a looking glass in his hand, nor as a Fichtian philosopher, to whom 'I am I' is sufficient, man first sees and recognises himself in other men. Peter only establishes his own identity as a man by first comparing himself with Paul as being of like kind. And thereby Paul, just as he stands in his Pauline personality, becomes to Peter the type of the genus homo." (Marx, 1990: 45)] 
But Thao translated it in the following way (1973: 20):

L'homme [...] se voit lui-même tout d'abord dans l'autre homme comme dans un miroir. Ce n'est que grâce à son rapport avec l'homme Paul comme avec un être semblable à lui-même, que l'homme Pierre entre en rapport avec lui-même comme avec un homme [italics mine: JDA]. [The man first sees himself in the other man as in a mirror. Peter only relates to himself as a man through his relation to another man, Paul, as being of like kind." (trans. mine: JDA)]

Thao's emphasis on the metaphor of the mirror is significant. He constantly employed the expression 'comme dans un miroir' (as in a mirror) throughout his RLC in order to explain the relation of reciprocity. In this way, Thao refused the idea of self-consciousness as a solipsistic relation of the self with the self while also sharply criticising Husserl's view that one's relationship with other egos is nothing but the result of a solipsistic comparison of one's own self with others (this theory was described in Husserl's Fifth Meditation; see Thao, 1975) ${ }^{2}$. Instead, to Thao, the experience of others is the source of selfconsciousness. We should add that Thao was aware that the internalised image of others cannot be reduced to an abstract image of others in general: 'he [the subject] recognizes himself in the image of the others in a form that is identified, modified, and oppositional or antagonistic according to whether it concerns his own group or different groups, friends or enemies' (Thao, 1984: 27 [1973: 52]). As is clear from this passage, Thao situated the LRL - and consequently consciousness - in the social structure of a class-divided society. Thus, the LRL is significantly affected by social and political determinations.

Thao's characterisation of the LRL as a site of social and political conflict and his appeal to a notion of 'inner language' in his explanation of consciousness obviously invite a comparison with Lev Vygotsky's psychology and Valentin N. Vološinov's semiology (cf. Vygotsky, 1962: Chapter 7; Vološinov 1973: 11-26). However, the present study is intended only as a preliminary exploration of the subject and such a comparison must therefore await proper consideration at another time. Nevertheless, we might sketch out the main outlines of a comparison here.

While we have no evidence that Thao had ever read Vološinov, Thao's semiology is remarkably close to that of Vološinov in some respects. We can enumerate the common hypotheses shared by Vološinov and Thao as follows:

a. Language is a human practice involved in social interactions;

b. Conscious contents depend on the internalization of language;

c. Language is the internalisation of public dialogue;

d. Subjectivity is the result of intersubjectivity;

e. The social origin of language conditions the forms of thought;

f. Consciousness cannot be reduced to physio-neurological mechanisms.

More generally, both authors criticise both abstract objectivism and radical subjectivism in linguistic thought. The similarities between the two authors most likely depend on them sharing a certain sociological insight, both arguing that they wanted to return to a conception of the social production of signs. However, a key difference is that Vološinov wanted to propose a philosophy of language as a philosophy of ideological signs, while Thao wanted to show how the Marxist approach to language can solve problems related to the phylogenetic origin of language and consciousness.

One main point of convergence between Thao and Vygotsky relates to the former's account of consciousness in terms of the internalization of the LRL. Again, we have no evidence that Thao had ever read Vygotsky. Nonetheless, they both believed that consciousness was an internalisation of social behaviour. However, Thao's approach parallelled that of Vygotsky only as concerns the phylogeny of language while Thao preferred to follow Jean Piaget's psychology in describing the ontogenetic formation of linguistic behaviour. Thao acceptedthat the development of language in the child was based upon the innate character of some modern human symbolic abilities (pointing, pantomime, play, and so on): the child simply reactivates the symbolic skills first put in place by our ancestors. To Vygotsky, on the other hand, language development in the child was the result of the internalisation and refunctionalisation of 'external' (social) language. Paradoxically, then, Thao's description of the linguistic skills of the child largely depends upon Piaget's psychology while his account of the evolution of language seems to be more similar to Vygotsky's approach. He also seems to coincide with Vygotsky regarding the formation of inner language, i.e., consciousness, in the adult. It should also be noted that for Thao language and thought have the same origin, whereas for Vygotsky (1962) they had two different sources.

\section{Language and praxis}

At this juncture, let us examine in more detail Thao's characterisation of the LRL as a social activity, a material behaviour, a dimension of the intercourse with other individuals in the production and reproduction of the means of existence. As such, the LRL is deeply influenced by the social and practical behaviour of a given society. In Thao's words: 'its meaning consists in the immediate expression of the very moment of material relations and it is this objective, not conscious, meaning that subjects first communicate to one another in their "material behaviour" [comportement materiel]' (Thao, 1984: 17 [1973: 35]). How exactly are we to take the idea of the LRL as 'the direct efflux' of material behaviour (Marx and Engels, 1998: 42)?

\footnotetext{
2 But it is necessary to remember that Husserl insisted that the experience of the world is intersubjective (see Husserl, 1973a, 123; 1968, 431; 1973b, 289, 390; 1973c, 5; 1974, 243; 1976, 469). For this reason, he had also analysed the nature of transcendental intersubjectivity (see Husserl, 1973a, 35, 182; 1959, $449 ; 1968,295,474 ; 1973 c, 110)$.
} 
According to Thao, 'in the dialectical flow of history [dans le mouvement dialectique de l'histoire], new meanings are always constituted which are at first unknown to consciousness in the language of real life, and only become the object of awareness [prise de conscience] after a period of time' (Thao, 1984: 17 [1973: 36]). Thus, Thao distinguished between two layers of meaning,[deux couches de significations]: i) conscious meanings and ii) not yet conscious meanings. The former includes meanings of which consciousness is already aware while the latter consists of meanings that the LRL has already produced and recorded even if they have not yet become conscious contents. Thao called conscious meaning idealized meaning and the non-conscious meaning as it is embedded in the LRL tendential meaning.

Each person employs signs which are already provided with an established meaning, but 'he says it involuntarily, for this meaning is imposed objectively by the force of circumstances outside consciousness, in the language of real life' (Thao, 1984: 19 [1973: 38]). In this case, meaning 'is directly produced by the material motion of the signs themselves, in so far as it is necessarily shaped by the motion of things' (Thao, 1984: 24 [1973: 47]). Indeed, the 'whole of the already acquired content of consciousness [...] has itself been established historically on previous forms of the language of real life.' Consequently, the LRL always gets ahead of both inner language and consciousness. This is the reason why the LRL also mediates the internalisation of a social way of thinking. We must now examine what Thao meant by language that is 'prior to consciousness' and how such language can be the source of conscious contents.

As a preliminary, it is important to consider briefly the Marxian conception of 'image' (Abbild). As is well known, in the Afterword to the Second German Edition of the Capital, Marx wrote: 'the ideal is nothing else than the material world reflected by the human mind, and translated into forms of thought [Bei mir ist umgekehrt das Ideelle nichts anders als das im Menschenkopf umgesetzte und übersetzte Materielle]' (Marx 1990: 25 [Marx and Engels, 1962c: 27]). And Engels wrote elsewhere: 'we again took a materialistic view of the thoughts in our heads, regarding them as images [Abbilder] of real things instead of regarding real things as images of this or that stage of the absolute concept. [...] Thereby the dialectic of concepts itself [die Begriffsdialektik] became merely the conscious reflex [der bewußte Reflex] of the dialectical motion of the real world [die dialektischen Bewegung der wirklichen Welt]' (Marx and Engels, 1962b: 292-293; trans. from Engels, 1946: Part IV). One might summarise the position of Marx and Engels, in a way relevant to our current concerns, as follows: i) the objective world precedes our knowledge of it and is the source of that knowledge, ii) contrary to idealism, the objective world is not the result of the operations of our thought, iii) our consciousness reflects, or corresponds to, social being - in other words, our consciousness is rooted in a historical and social context. One could add that consciousness is not a mere mirror-reflection of objective being but is rather the inner reflection of real and practical interactions with the surrounding social and physical environment.

To Thao, consciousness could be seen as the image of the external world, 'l'image du monde extérieur' (Thao, 1973: 55) but his conception of the 'image' relationship was informed by his understanding of the LRL. We have already seen how the LRL is the precondition of every form of conscious experience and how it informs the way we perceive the physical environment as well. Now, assuming that the external world already includes the social dimension, it follows that consciousness also reflects shared ways of thinking which arise in the LRL, though those ways of thinking are at first unconscious.

To explain this point, Thao took an example from Marx's Capital:

The celebrated Franklin, one of the first economists, after Wm. Petty, who saw through the nature of value, says: "Trade in general being nothing else but the exchange of labour for labour, the value of all things is ... most justly measured by labour." (The works of B. Franklin, \& c., edited by Sparks, Boston, 1836, Vol. II., p. 267.) Franklin is unconscious that by estimating the value of everything in labour, he makes abstraction from any difference in the sorts of labour exchanged, and thus reduces them all to equal human labour. But although ignorant of this, yet he says it. He speaks first of "the one labour", then of "the other labour", and finally of "labour", without further qualification, as the substance of the value of everything. (Marx 1990: 43; cf. MEW I: 65 [(17a) Note zur 2. Ausgabe])

In other words, when Franklin was analysing the nature of trade, he unconsciously used a notion of labour which was similar to that developed by Marx some years later. Franklin could unconsciously use a Marxian notion of value because it refers to a fact that already existed and "has been reflected, unknown to the author, in the tendential meaning of his discourse which, while presented as a perfectly conscious theoretical exposition nevertheless includes the non-conscious moment of the language of real life" (Thao 1984[1973]: 24-25). There are clear parallels with this position in fact with Lecercle's (2006: 96) own suggestion linking language, consciousness, and social relations. On the one side, then, the LRL is the condition for thinking our actual life and having conscious representations of it. On the other side, it 'freezes and veils' that same representation. The LRL is not neutral but it is rather 'always already endowed with a public meaning' (Lecercle, 2006: 174). That is so exactly because the LRL conveys unconscious representations of facts emerging from the objective dimension of socioeconomic relations.

Interestingly, Thao seems to develop an idea which had already been proposed by Merleau-Ponty in the early 1950s:

Articulated language is itself only the highest point of concentration of a duller language that humans speak to each other by the symbols that their economic, political, religious and moral coexistence creates. [...] A theory of truth would, therefore, be superficial if it did not take into account, along with the speaking subject and the linguistic community, the living subject, wanting, evaluating, creating and working in the historical community, and the reports of truth that individuals can and can tie with that historical community. [le langage articulé n'est lui-même que le plus haut point de concentration d'un langage plus sourd que les hommes se parlent les uns aux autres par les symboles que crée leur coexistence économique, politique, religieuse et morale. [...] Une théorie de la vérité serait donc superficielle 
si elle ne prenait en considération, outre le sujet parlant et la communauté linguistique, le sujet vivant, voulant, évaluant, créant et travaillant dans la communauté historique, et les rapports de vérité qu'il peut et pourra nouer avec elle.] (Merlau-Ponty, 2010: 1828; trans. mine: JDA)

We cannot rule out the possibility that both Merleau-Ponty and Thao had been seriously influenced by the Husserlian notion of 'lifeworld', Lebenswelt (cf. Husserl, 1976, 1992, 2008). Both scholars attempted to develop that notion in order to explain the social and embodied origins of conscious contents while at the same time attempting to avoid the risks of idealism and solipsism that the Husserlian account contained.

Some questions emerge from all that has been said. How far has labour contributed to the formation of language? Does language convey the mark of its social origins? How do the social origins of language affect consciousness? How far is consciousness affected by language and its social origins? No better answer can be given than the following. Practical life is the pre-condition for having the emergence of certain forms of language. But the LRL is not something that is added to social relations and the production of the means of existence. To Thao, the LRL is an essential factor of practical life one of the three moments of the material behaviour of humans (cf. Thao 1984 [1973]: 17). These are i) the LRL, ii) material activity (interactions with the physical environment), and iii) material relations (interactions with the social environment). This conception is particularly clear when we take into account Thao's theory of language origins. To Thao, social practice is the most decisive factor in the evolution of language. Furthermore, there is a parallelism between tool-making and symbolic behaviour. Thus, for Thao, the relationship between communicational activity (cries and simple gestures) and emotional states in higher primates corresponds to the relationship between their instrumental use of objects (natural instruments) and the immediate needs thereby satisfied. To put it another way, the form of life of apes and anthropoids is largely based on immediate need situations as their communication systems are. During the recession of tropical forests toward the end of the Tertiary Period (2.58 ma; ma: million years ago), Thao wrote, the first specimens of Australanthropus (i.e. Australopithecus) began to live in groups and to work in coordination to survive and adapt themselves to new environmental conditions. The Australanthropus prepared and conserved instruments (purposeful tool-modifying for a future eventuality) and obtained means of subsistence from collective hunting. Those cooperative activities required a certain distance between individuals. As a result, Australanthropus had to perform guidance gestures.

Convinced that labour must be regarded as the background against which human symbolic behaviour arises, Thao attempted to work out a position in which paleoanthropological findings can be interpreted as supports for describing the development of both symbolic skills and sophisticated forms of conscious experience. Thus, Thao combined the findings of palaeoarchaeology, such as petrified skeletal remains, bone fragments, footprints and associated evidence, stone tools, artefacts, and settlement localities, with hypotheses about the symbolic behaviour of our ancestors. In doing so, Thao's approach to the study of language evolution was largely based on the notion of the LRL as interwoven with the practical life of the species within the physical environment.

\section{Concluding remarks}

Thao was one of the few Marxists to have taken the notion of LRL seriously. Indeed, the distinctive contribution that Thao made was to employ the notion of LRL to explain the origins of conscious contents. But we have seen that not only does LRL convey un- and preconscious significations, it also supports all intellectual activity. On that basis, some elements of Thao's theory of LRL could be developed further. For example, if we assume that the LRL is in general the ultimate source of systems of arbitrary signs, then we can reason that it is also the basis for scientific metalanguages, including that of linguistics. In other words, the scientific metalanguage of linguistics, with all its ambiguities, imprecision, unconscious premises and so forth, could be seen to arise from linguists' real working practices and not the other way around. By this, we could re-affirm the position that real practice (including working knowledge, available technologies, working relations, institutions, etc.) largely orients our ways of thinking. Hence, science does not differ from any other ideological form. Furthermore, we have also focused on the fact that the LRL is radically embodied. As a result, the partially unconscious behaviour of the LRL seems to involve what Bourdieu (1991) calls a peculiar form of 'bodily hexis' (hexis corporelle), i.e., a long-lasting organization of dispositions. However, it is not enough to say that the LRL is embodied; the body of the speaker cannot be reduced to a purely natural fact. Consequently, we are not dealing with the embodied approach to language suggested by Lakoff and Johnson (2003). The 'embodied' nature of language must embrace the social and practical life of its users. As Lecercle (2006: 182) puts it, the speaker of the LRL is 'the "labouring" body of praxis.' In this way, the notion of an autonomous individual as the basis of linguistic theory is radically questioned.

As a further consideration, we may note that we have so far only pointed out the social nature of the LRL while underplaying the fact that the LRL also interacts with the physical environment. A key illustration of this interaction is, of course, the already mentioned pointing gesture which is still at work, though implicitly, in gaze during language interaction. The semiotic intentionality of pointing gestures may therefore be taken as the source of the experience of the mind-independent world, i.e., the shared target of common efforts, discourses, science, and so on (cf. Bimbenet, 2011: 197199). We cannot underestimate the role of Thao's phenomenological background in such a treatment. Husserl had already described the role of perception in determining the meaning of demonstrative expressions such as this (cf. Husserl, 1952, Sixth Investigation, $\S 5$ ). And following him, although taking into account fully formed language, Karl Bühler argued that demonstrative expressions required gesture and perception to specify their meaning or reference (cf. Bühler, 1934: 90). Interestingly, the same attempt to 
find the origins of consciousness and language by adapting the Husserlian theory of intentionality to semiotics could be observed in the writings of Hendrik Pos (cf. Pos, 2013: 117, 119).

As a final point, we might ask why Marxism has seldom drawn attention to the LRL despite the fact that it might be considered a key notion for the explanation of language behaviour from a dialectical materialist point of view. It is true that some Marxist scholars have drawn on the notion in treating ideological issues but they were for the most part philosophers rather than linguists. One factor is that the notion of LRL clearly interfaces with several academically distinct fields of research: linguistics, semiotics, sociology, philosophy of mind, political philosophy, psychology, and so forth. That indeed is its strength, but it can also be its weakness. Nonetheless, it remains to be seen whether the LRL, particularly in Thao's extension of the conception into the domain of linguistics and semiotics proper, might have heuristic potential at a time when scholars are widely discussing issues which cut across traditional disciplinary boundaries relating to social cognition, embodied cognition, extended mind, the integration of communication and action, cultural niche-construction, misinformation/ disinformation, normativity in language, and many other topics.

\section{References}

Althusser, Louis, 1995. The Future Lasts Forever. A Memoir. Translated by Richard Veasey. The New Press, New York [First French Edition: 1992. L'avenir dure longtemps (suivi de Les faits). Paris: Stock/IMEC. Second French Edition: 1994. Réédition augmentée et présenté par Olivier Corpet et Yann Moulier Boutang. Paris: Le Livre de poche. Third French Edition: 2013. Édition augmentée. Paris: Flammarion.].

Aubert-Nguyen, Hoai huong, 2013. Lectures d L’Histoire de Kiều. Étude de deux articles de Tran-Duc-Thao: «Comprendre la valeur de la littérature ancienne» et «Le contenu social de L'Histoire de Kiều». Benoist \& Espagne 2013, pp. 115-132.

Barthes, Roland, 1951. Sur le livre de Tran-Duc-Thao, Phénoménologie et matérialisme dialectique, Editions Minh Tân. CoMBAT. October 11.

Baudrillard, Jean, 1972. Pour une critique de l'économie politique du signe. Gallimard, Paris.

Bimbenet, Etienne, 2011. L'animal que je ne suis plus. Gallimard, Paris.

Bourdieu, Pierre, 1977. L'économie des échanges linguistiques. Lang. Fr. 34, 17-34.

Bourdieu, Pierre, 1991. Language and Symbolic Power. Polity Press, Cambridge (UK).

Bühler, Karl, 1934. Sprachtheorie. Die Darstellungsfunktion der Sprache. G. Fischer, Jena.

Camaioni, Luigia, 1993. In: Nadel, Jacqueline, Camaioni, Luigia (Eds.), The Development of Intentional Communication: A Re-analysis. New Perspectives in Early Communicative Development. Routledge, London, pp. 82-96.

Caveing, Maurice, 1974. «Recherche sur l'Origine du Langage et de la Conscience» par Trân Duc Thao. Raison Presente 31, $118-124$.

Curea, Anamaria, 2015. Entre expression et expressivité: l'école linguistique de Genève de 1900 à 1940: Charles Bally, Albert Sechehaye, Henri Frei. ENS Éditions, Lyon.

D'Alonzo, Jacopo, 2016. Tran-Duc-Thao: A Marxist Theory on Origins of Human Language. Theoria et Historia Scientiarum 13 The origins and development of language: a historical perspective. Nicolaus Copernicus University Press, pp. 103-120. https://doi.org/10.12775/ths.2016.007.

D'Alonzo, Jacopo, 2017a. La semiologia dialettica di Tran-Duc-Thao: Alcune considerazioni su Saussure, fenomenologia e strutturalismo. Acta Struct. - Int. J. Struct. Res. 2. https://doi.org/10.19079/actas.2017.1.5, 1.53-86.

D’Alonzo, Jacopo, 2017b. L'origine del linguaggio e della coscienza. Storia di un libro mai pubblicato: dal carteggio inedito tra Ferruccio Rossi-Landi e TranDuc-Thao. Acta Struct. 2 (1), 87-152. https://doi.org/10.19079/actas.2017.1.87.

Derrida, Jacques, 2004. Eyes of the University: Right to Philosophy 2. Translated by Jan Plug and others. Stanford University Press, Stanford. First Edition 1990. Du droit à la philosophie.

Dosse, François, 1991. Histoire du Structuralisme Tome I: le champ du signe, 1945-1966. La Découverte, Paris.

Dosse, François, 1992. Histoire du Structuralisme Tome II: le chant du cygne, 1967 à nos jours. La Découverte, Paris.

D’Urso, Andrea, 2014. Denaro linguistico e plusvalore ideologico. Krypton 4, 52-61.

Engels, Friedrich, 1946. Ludwig Feuerbach and the End of Classical German Philosophy. Progress Publishers, Moscow.

Engels, Friedrich, 1987. Dialectics of Nature. English Translation by Clemens Dutt. Progress Publishers, Moscow.

Eilan, Naomi, Hoerl, Christoph, McCormack, Teresa, Roessler, Johannes, 2005. Joint attention: Communication and Other Minds: Issues in Philosophy and Psychology. Clarendon Press, Oxford.

Federici, Silvia, 1970. Viet Cong philosophy: Tran-Duc-Thao. Telos 6, 104-117.

Feron, Alexandre, 2014. Qui est Tran-Duc-Thao? Vie et œvre d'un philosophe vietnamien. Contretemps, Blog. Consulted on February, 5, 2014. http://www. contretemps.eu/interventions/qui-est-tr\%E1\%BA\%A7n-\%C4\%91\%E1\%BB\%A9c-th\%E1\%BA\%A3o\%C2\%A0-vie-\%C5\%93uvre-dun-philosophevietnamien.

Frédéric, François, 1974. Trân Duc Thao et les Recherches sur l’Origine et le Développement du Langage. La Pensée 174, $32-52$.

Giao, Nguyên Ngoc, 1988. Ecrits et reperes biographiques. Tran-Duc-Thao, La Philosophie de Staline I. Editions May, Paris, pp. 57-62.

Goux, Jean-Joseph, 1968. Marx et l'inscription du travail. Tel Quel 33, 188-211.

Haudricourt, André, 1974. Tran-Duc-Thao: Recherches sur l'origine du langage et de la conscience. Editions sociales, Paris, 1973. La Pensée 173:136.

Hémery, Daniel, 2013. Itinéraire I. Premier exil. Benoist and Espagne, pp. 47-61.

Husserl, Edmund, 1973a. In: Strasser, S. (Ed.), Husserliana 1. Cartesianische Meditationen und Pariser Vorträge. Martinus Nijhoff, The Hague, Netherlands [= Hua I.].

Husserl, Edmund, 1952. In: Biemel, Marly (Ed.), Husserliana 4. Ideen zur einer reinen Phänomenologie und phänomenologischen Philosophie. Zweites Buch: Phänomenologische Untersuchungen zur Konstitution. Martinus Nijhoff, The Hague, Netherlands [= Hua IV.].

Husserl, Edmund, 1976. In: Biemel, Walter (Ed.), Husserliana 6. Die Krisis der europäischen Wissenschaften und die transzendentale Phänomenologie. Eine Einleitung in die phänomenologische Philosophie. Martinus Nijhoff, The Hague, Netherlands [= Hua VI.].

Husserl, Edmund, 1959. In: Boehm, Rudolf (Ed.), Husserliana 8. Erste Philosophie (1923/1924). Zweiter Teil: Theorie der phänomenologischen Reduktion. Martinus Nijhoff, The Hague, Netherlands [= Hua VIII.]

Husserl, Edmund, 1968. In: Biemel, Walter (Ed.), Husserliana 9. Phänomenologische Psychologie. Vorlesungen Sommersemester. 1925. Martinus Nijhoff, The Hague, Netherlands [= Hua IX.].

Husserl, Edmund, 1973b. In: Kern, Iso (Ed.), Husserliana 14. Zur Phänomenologie der Intersubjektivität. Texte aus dem Nachlass. Zweiter Teil. 1921-1928. Martinus Nijhoff, The Hague, Netherlands [= Hua XIV.].

Husserl, Edmund, 1973c. In: Kern, Iso (Ed.), Husserliana 15. Zur Phänomenologie der Intersubjektivität. Texte aus dem Nachlass. Dritter Teil. 1929-1935. Martinus Nijhoff, The Hague, Netherlands [= Hua XV.].

Husserl, Edmund, 1974. In: Janssen, Paul (Ed.), Husserliana 17. Formale and transzendentale Logik. Versuch einer Kritik der logischen Vernunft. Martinus Nijhoff, The Hague, Netherlands [= Hua XVII.].

Husserl, Edmund, 1992. In: Smid, Reinhold N. (Ed.), Husserliana 29. Die Krisis der europaischen Wissenschaften und die transzendentale Phänomenologie. Ergänzungsband. Texte aus dem Nachlass 1934-1937. Kluwer Academic Publishers, The Hague, Netherlands [= Hua XXIX.].

Husserl, Edmund, 2008. In: Sowa, Rochus (Ed.), Husserliana 39. Die Lebenswelt. Auslegungen der vorgegebenen Welt und ihrer Konstitution. Texte aus dem Nachlass (1916-1937). Springer, New York [= Hua XXXIX.]. 
Israël, Stéphane, 2005. Les Études et la guerre: Les Normaliens dans la tourmente (1939-1945). Éditions Rue d'Ulm, Paris. http://books.openedition.org/ editionsulm/673.

Jakobson, Roman, 1963. Essais de linguistique générale. French translation by Nicolas Ruwet. Edition de Minuit, Paris.

Lakoff, George, Johnson, Mark, 2003. Metaphors We Live By. University of Chicago Press, Chicago.

Latouche, Serge, 1973. Linguistique et économie politique. L'Homme et la société 28 (1), 51-70.

Lecercle, Jean-Jacques, 2006. A Marxist Philosophy of Language. trans. by Gregory Elliott. Brill, Leiden [First French Edition: 2004. Une philosophie marxiste du langage. Paris: PUF.].

Lefebvre, Henri, 1966. Le langage et la société. Gallimard, Paris.

Lefebvre, Henri, 1971. Au-delà du structuralisme. Editions Anthropos, Paris.

Lenin, I. Vladimir, 1972. Materialism and Empirio-criticism. Foreign Languages Press, Peking [First edition: 1908.].

Lepschy, Giulio, 1966. La linguistica strutturale. Einaudi, Torino.

Lyotard, Jean-François, 1991. Phenomenology. Translated by Brian Beakley. State University of New York Press, Albany [Firts Edition: 1954. La Phénoménologie. Paris: PUF.].

Marx, Karl, 1990. Capital. A Critique of Political Economy. English translation by Samuel Moore and Edward Aveling. Dietz Verlag, Berlin.

Marx, Karl, Engels, Friedrich, 1958. Marx-Engels-Werke III. Schriften 1845-1846 [Die deutsche Ideologie. Thesen über Feuerbach.]. Dietz Verlag, Berlin [= MEW III.].

Marx, Karl, Engels, Friedrich, 1962a. Marx-Engels-Werke XX. Anti-Dühring. Dialektik der Natur. Friedrich Engels: Herrn Eugen Dührings Umwälzung der Wissenschaft (Anti-Dühring). Dialektik der Natur [includes Anteil der Arbeit an der Menschwerdung des Affen.]. Dietz Verlag, Berlin [= MEW XX.].

Marx, Karl, Engels, Friedrich, 1962b. Marx-Engels-Werke XXI. Schriften Mai 1883-Dezember 1889 [Engels: Der Ursprung der Familie, des Privateigentums und des Staats. Ludwig Feuerbach und der Ausgang der klassischen deutschen Philosophie. Zur Geschichte des Bundes der Kommunisten. Die Rolle der Gewalt in der Geschichte.]. Dietz Verlag, Berlin [= MEW XXI.].

Marx, Karl, Engels, Friedrich, 1962c. Marx-Engels-Werke XXIII. Das Kapital - Erster Band. Das Kapital. Kritik der politischen Ökonomie. Buch I: Der Reproduktionsprozeß des Kapitals. Dietz Verlag, Berlin [= MEW XXIII.].

Marx, Karl, Engels, Friedrich, 1968. L'idéologie allemande. Editiones sociales, Paris.

Marx, Karl, Engels, Friedrich, 1998. The German Ideology. Part One with selections Form Parts Two and Three, together with Marx's 'Introduction to a Critique of Political Economy'. Prometheus Books, Amherst (NY).

Melançon, Jérôme, 2016. Tran-Duc-Thao, las transformaciones de una vida. Tran-Duc-Thao, La filosofía de Stalin. Doble Ciencia, Santiago de Chile, pp. 11-28.

Merlau-Ponty, Maurice, 2010. In: Lefort, Claude (Ed.), Travaux et projet d'enseignement. Maurice Merlau-Ponty, Euvres. Gallimard, Paris, 1809-1828.

Morgenstern, Aliyah, Leroy, Marie, Mathiot, Emmanuelle, 2008. Le pointage chez l'enfant: du gestuel au linguistique. Congrès Mondial de Linguistique Française. EDP Sciences. https://www.linguistiquefrancaise.org/articles/cmlf/abs/2008/01/cmlf08170/cmlf08170.htm.

Papin, Philippe, 2013. Itinéraire II. Les exils intérieurs. Benoist and Espagne, pp. 62-89.

Pos, J. Hendrik, 2013. In: Flack, Patrick (Ed.), Le langage comme fonction symbolique. Écrits sur le langage. Sdvig Press, Genève \& Losanne, pp. 113-128 [First Edition: 1933. De taal als symbolishe functie. De Uidrukkingswijze der wetenschap ed. by L.E.J. Brouwer. Groningen: Noordhoff.].

Puech, Christian, 2013a. L'esprit de Saussure: reception et héritage (l'héritage linguistique saussurien: Paris contre Genève). Les dossiers d'H[istoire]E [pistémologie]L[angage] 3,1-9.

Puech, Christian, 2013b. Présentation du dossier: est-il temps de faire l'histoire des structuralismes? Dossiers d'H[istoire]E[pistémologie]L[angage] 3, 1-12.

Revel, Jean-François, 1997. Le voleur dans la maison vide. Mémoires. Plon, Paris.

Ricœur, Paul, 2004. À l'école de la phénoménologie. Vrin, Paris.

Rossi-Landi, Ferruccio, 1977. Linguistics and Economics [1970-1971] [= Janua Linguarum, Series Maior 81.]. Mouton, The Hague [First Edition: 1974. Part 8 of Volume XII: Linguistics and adjacent arts and sciences, of Current Trends in Linguistics, 1787-2017, The Hague: Mouton.].

Rossi-Landi, Ferruccio, 2003. Il linguaggio come lavoro e come mercato. Una teoria della produzione e dell'alienazione linguistiche. Bompiani, Milano [First Edition: 1968.].

Rossi-Landi, Ferruccio, 2016. Linguistica ed economia. Mimesis, Milano.

de Saussure, Ferdinand, 1916. Cours de linguistique générale. Payot, Paris [New Edition: 1995]. [= CLG.].

Schaff, Adam, 1968. Introduction à la sémantique. Traduit du polonais par G. Lisowski. Anthropos, Paris.

Schaffer, H. Rudolph, 1984. The Child's Entry into a Social World. Academic Press, London.

Sève, Lucien, 1984. Structuralisme et dialectique. Editions Sociales, Paris.

Sofia, Estanislao, 2013. In: Normand, Claudine, Sofia, Estanislao (Eds.), Petite histoire de la notion saussurienne de la valeur. Espace théorique du langage. Academia, Louvain-La-Neuve, pp. 29-64.

Thao, Tran Duc, 1946a. Marxisme et phénoménologie. Revue Internationale 2, 68-174.

Thao, Tran Duc, 1946b. Sur l'Indochine. Les Temps Modernes 18, 878-900.

Thao, Tran Duc, 1947a. Les relations franco-vietnamiennes. Les Temps Modernes 18, 1053-1067.

Thao, Tran Duc, 1947b. Sur l'interprétation trotzkyste des événements d'Indochine. Les Temps Modernes 21, 1697-1705.

Thao, Tran Duc, 1948. La Phénoménologie de l'Esprit et son contenu réel. Les Temps Modernes 36, 492-519.

Thao, Tran Duc, 1949. Existentialisme et matérialisme dialectique. Rev. Metaphys. Morale 58 (2/3), 317-329.

Thao, Tran Duc, 1951. Phénoménologie et Matérialisme Dialectique. Minh Tan, Paris.

Thao, Tran Duc, 1973. Recherches sur l'origine du langage et de la conscience. Editions Sociales, Paris.

Thao, Tran Duc, 1984. Investigations into the Origin of Language and Consciousness [Boston Studies in the Philosophy of Science 44.] English translation by Daniel J. Herman \& Robert L. Armstrong. D. Reidel, Dordrecht Boston.

Thao, Tran Duc, 1974. De la phénoménologie à la dialectique matérialiste de la conscience (I). La Nouvelle Critique 79/80, 37-42. English translation by Robin Muller.

Thao, Tran Duc, 2009a. From phenomenology to the materialist dialectic of consciousness (I). Graduate Faculty Journal 30 (2), 297-309.

Thao, Tran Duc, 1975. De la phénoménologie à la dialectique matérialiste de la conscience (II). La Nouvelle Critique 86, 23-29.

Thao, Tran Duc, 2009b. From Phenomenology to the Materialist Dialectic of Consciousness (II). Graduate Faculty Journal 30.2:309-323. English translation by Robin Muller.

Thảo, Trần Đức, 1991. La formation de l'homme.Introduction à l'origine de la société, du langage et de la conscience. Published by the author, Paris.

Thảo, Trần Đức, 1993. Note biographique - La logique du présent vivant. Les Temps Modernes 568, 154-168.

Thao, Van Trinh, 2004. Les compagnons de route de Hô Chi Minh. Karthala, Paris.

Thao, Van Trinh, 2013. Quelques jalons dans le parcours philosophique de Tran-Duc-Thao. Benoist and Espagne, pp. 90-114.

Tomasello, Michael, 1995. In: Moore, Chris, Dunham, Phil (Eds.), Joint Attention as Social Cognition. Joint Attention: Its Origins and Role in Development. Psychology Press, Hove (UK), pp. 103-130.

Vygotsky, Lev, 1962. Thought and Language. ed. and trans. by Eugenia Hanfmann, Gertrude Vakar, Norris Minnick. MIT Press, Cambridge.

Vološinov, Valentin Nikolaevich, 1973. Marxism and the Philosophy of Language [Studies in Language 1]. English translation by Ladislav Mateika and I.R. Titunik. Seminar Press, New York \& London [First edition: Leningrad 1929].

\section{Further reading}

Benoist, Jocelyn, Espagne, Michel (Eds.), 2013. L'itinérairede Tran-Duc-Thao. Phénoménologie et transfert culturel. Armand Colin, Paris. Marx, Karl, Friedrich, Engels, 1956. Marx-Engels-Werke I. Schriften 1839-1844. Dietz Verlag, Berlin [= MEW I.]. 